COMmENTARY ON COVID-19 AND THE FoOd SyStem

\title{
Fostering food equity in an immigrant neighborhood of New York City during COVID-19
}

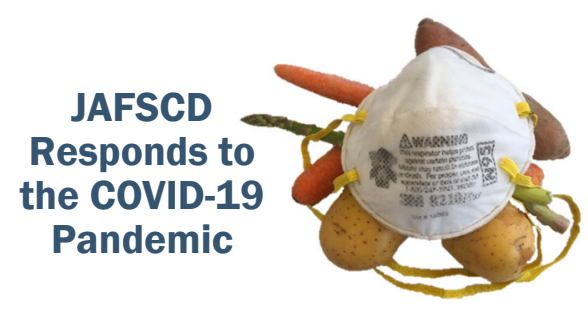

\author{
Valerie Imbruce * \\ Binghamton University
}

Submitted September 29, 2020 / Published online December 9, 2020

Citation: Imbruce, V. (2020). Fostering food equity in an immigrant neighborhood of

New York City during COVID-19. Journal of Agriculture, Food Systems, and Community

Development, 10(1), 251-255. https://doi.org/10.5304/jafscd.2020.101.028

Copyright (C 2020 by the Authors. Published by the Lyson Center for Civic Agriculture and Food Systems. Open access under CC-BY license.

\begin{abstract}
Food equity includes the right to food that is culturally appropriate. Immigrant neighborhoods can be sites of contestation over who participates in the production, distribution, and consumption of food. Manhattan's Chinatown is a good example of a neighborhood where food is central to its commerce, cultural heritage, and reputation as a tourist destination. The coronavirus' origin in China caused immediate material impact on Chinese restaurants and food purveyors in New York City as well as in other cities with major populations of Chinese people. Chinatown suffered disproportionate closures of its grocery stores, restaurants, and produce vendors due to COVID-19 as compared to other neighborhoods in NYC. The grassroots response to this crisis is a reminder that people have the power to use food to assert the society that they desire, to shape a highly contested urban space, and to claim their right to the city.

* Valerie Imbruce, Director, External Scholarships and Undergraduate Research Center; Research Associate, Environmental Studies; Binghamton University; vimbruce@binghamton.edu

\section{Funding Disclosure}

This work has been supported by Binghamton University's Sustainable Communities Transdisciplinary Area of Excellence.

\section{Acknowledgments}

I have several project partners who have facilitated my engagement with community organizations in Chinatown and people who care about its food system. I thank Stephan Fan for initiating our collaboration with City as Living Laboratory (CALL) and introducing me to Yin Kong, director of Think!Chinatown. Olivia Georgia and Liza Cucco at CALL have organized walks and virtual forums to foster dialogue about food, gentrification, cultural heritage, and the environment in Chinatown that have shaped my perspective. I am grateful for the assistance of Binghamton University undergraduates Raymond Peng and Stella Huang. Finally, I thank Yin and her research assistant Alexandra Smith, and my colleague Stella Yi at New York University, for commenting on this manuscript before submission.
\end{abstract}




\section{Keywords}

Urban Food Systems, Food Equity, COVID-19, Pandemic, Community Engagement, Resilience, Chinatown, New York City

Seven months before the unpredictable lockdown of New York State due to COVID-19, New York $\checkmark$ City Council released an agenda to improve food equity across the city. The report opens with the assertation that "Food has the power to connect us to cultures of past and present, to our neighbors, our communities and our Earth. ... Every neighborhood should have food businesses that reflect the community's cultures and diversity" (Johnson, 2019, p. 4). This is a powerful vision that recognizes the centrality of food to the fabric of multicultural, global cities like New York. It also evokes the wellestablished idea that who we are as individuals and as a society is reflected by what we eat (Gabaccia, 1998; Ginanneschi, 2020; Mintz, 1996).

A less celebrated idea is that we are what we won't eat. Foods of minority peoples that were once embraced by majority culture can revert to being considered disgusting or otherwise unconsumable as political and economic tensions rise between nation states (King, Fu, Brown, \& Santacaterina, 2020). The coronavirus' origin in China caused immediate material impact on Chinese restaurants and food purveyors in NYC as well as other cities with major populations of Chinese. These businesses experienced an economic downturn even before cities went into lockdown, sending a ripple effect through the supply chain. An Asian vegetable farmer, whose family farm has supplied Chinatown for three generations, saw a swift decline of more than half of their usual sales, a pattern that cascaded out across their Florida growing region (S. Chen, personal communication, April 1, 2020; Campbell \& McAvoy, 2020). Tourists, a mainstay of the food economy in Chinatown, simply stopped coming, and residents were afraid to go out in the face of overt discrimination (Barron, 2020; Sietsema, 2020).

Eating and enjoying the food of others is not enough to surmount the structural inequities that separate people by class, race, ethnicity, and citizenship (Garcia, DuPuis, \& Mitchell, 2017; Ku, Manalansan, \& Mannur, 2013; Ray, 2016). This is why government plans to enable equal access to fresh, healthy and culturally appropriate foods are critical. Such plans, however, often frame minority communities as those in need of food rather than as producers of culturally specific practices. Acknowledging this difference can lead to programs that support and uplift ethnic entrepreneurs and civil society organizations, which are critical to just and sustainable food systems.

Manhattan's Chinatown is a good example of a low-income, immigrant neighborhood where food is central to its commerce, cultural heritage, and reputation as a tourist destination. Chinese-American entrepreneurs developed their own food system to deliver culturally specific foods since Chinatown's inception as a racialized ghetto. The food sector is a common place of work for new immigrants (Ray, 2017). Today, NYC has multiple Chinatowns across its five boroughs that are not solely ethnic enclaves, but are interconnected global hubs composed of small independent operators rather than the national and international franchises that have come to dominate food distribution and service elsewhere (Hum, 2014; Imbruce, 2016). The food sector represents the largest proportion of Manhattan Chinatown's businesses. Twenty-six percent of commercial and up to $91 \%$ of industrial use supports restaurants, grocery distribution, and food manufacturing $(\mathrm{Li}, 2011)$. This uniquely fosters interdependence between businesses and among residents. A grocery store owner of 25 years in Manhattan's Chinatown says she is in this business, "Because by doing this, we can help people. By helping others, we also help ourselves" (A. Yee, personal communication, July 20, 2020).

Compared to other neighborhoods in NYC, Chinatown has suffered disproportionate closures of its grocery stores, restaurants, and produce vendors due to Covid-19 (Yi et al., 2020). The neighborhood has lost over $20 \%$ of these businesses, including cornerstone restaurants that are cultural institutions. 
Over half the street vendors selling fruits and vegetables had already been on decline over the last decade (Imbruce, personal observation). The specter of gentrification looms large behind these closures. Many people fear that this is accelerating the processes of displacement of Chinese-American residents, decline in households with children, and loss of mom-and-pop businesses already underway (Li, 2011; Young, 2020).

The grassroots response to this crisis is a reminder that people have the power to use food to assert the society that they desire, to shape a highly contested urban space, and to claim their right to the city (Zukin, 2010). There have been many initiatives beyond the length of this commentary, but I will highlight several of the activists, artists, and entrepreneurs that I am inspired by. Grace Young, a James Beard award winning cookbook author and video maker, has collaborated with the online museum Poster House on the video series Coronavirus: Chinatown Stories. These stories humanize and give heart to the struggles of Chinese restaurant owners as they face decisions to close. Think!Chinatown, a small nonprofit that uses storytelling and the arts to build community, connected local stakeholders with city leadership to support the declining wholesale produce industry in Chinatown. They have found that the tools needed to support practical solutions are present within the community and that intergenerational adaptation has been critical for resiliency. They began "Assembly for Chinatown," a collaboration with the woman-led design collective A+A+A Studio, to design Department of Transportation-compliant and attractive outdoor dining solutions (see Figures 1 and 2). Joe Boo, the son of an Asian produce wholesaler, started an e-commerce site, asian-veggies.com, simply to help his father move produce that otherwise would have rotted in his warehouse. He also partnered with Welcome to Chinatown, a philanthropic organization that sprang up in response to the pandemic, to donate produce bags of Asian fruits and veggies for homebound seniors (Greens for Good). Now Joe, a software salesman, is finding connection with the food of his Malaysian-Chinese upbringing. He has found a niche in online Asian grocery sales, so he is now working above and beyond his full-time job to build this business.

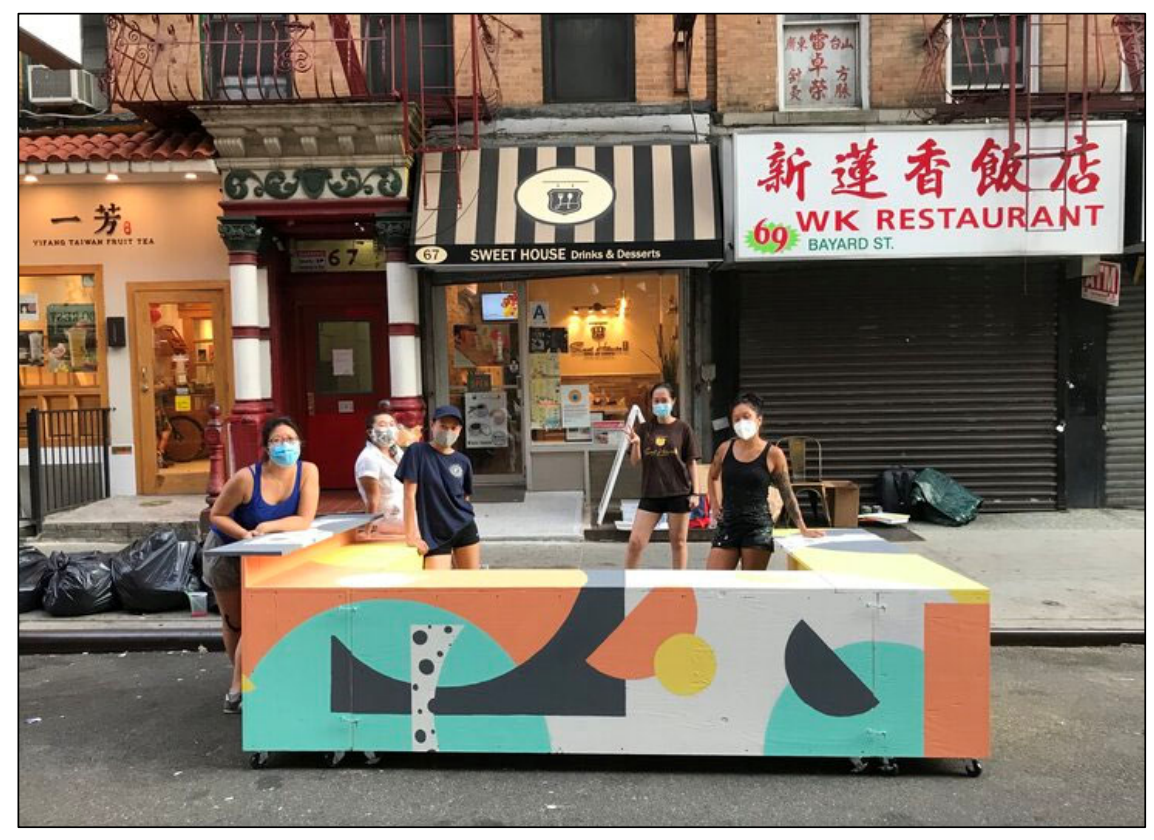

Figure 1. Think!Chinatown and women-led design studio A+A+A build new outdoor dining to support Sweet House Drinks \& Desserts on 67 Bayard Street in their program Assembly for Chinatown. Photo by Think!Chinatown.
There are many more grassroots initiatives of note, from Send Chinatown Love, to Heart of Dinner and Stir Fry Meals on Wheels. I have had a unique view of this moment in large part due to the sustained engagement I have had with City as Living Laboratory (CALL) to bridge art and science for the public education of sustainability challenges. Together, we developed a story map to uncover the connections between Chinatown's vibrant marketplace and the farms that support it. The story map showcases the forward-looking urban design ideas of Stephen Fan that address the antagonistic 
goals of street-level microentrepreneurship and orderliness on sidewalk space (CALL, 2020).

There is no shortage of vision for a just and equitable society. And there is incredible talent, energy, and in some cases, resources to devote to food sovereignty and people's right to Manhattan's Chinatown. Ethnic food became a category in American consciousness as a tidy way to position the foodways of the dominant first immigrant groups to America against other newcomers (Ray, 2016). We are a nation of

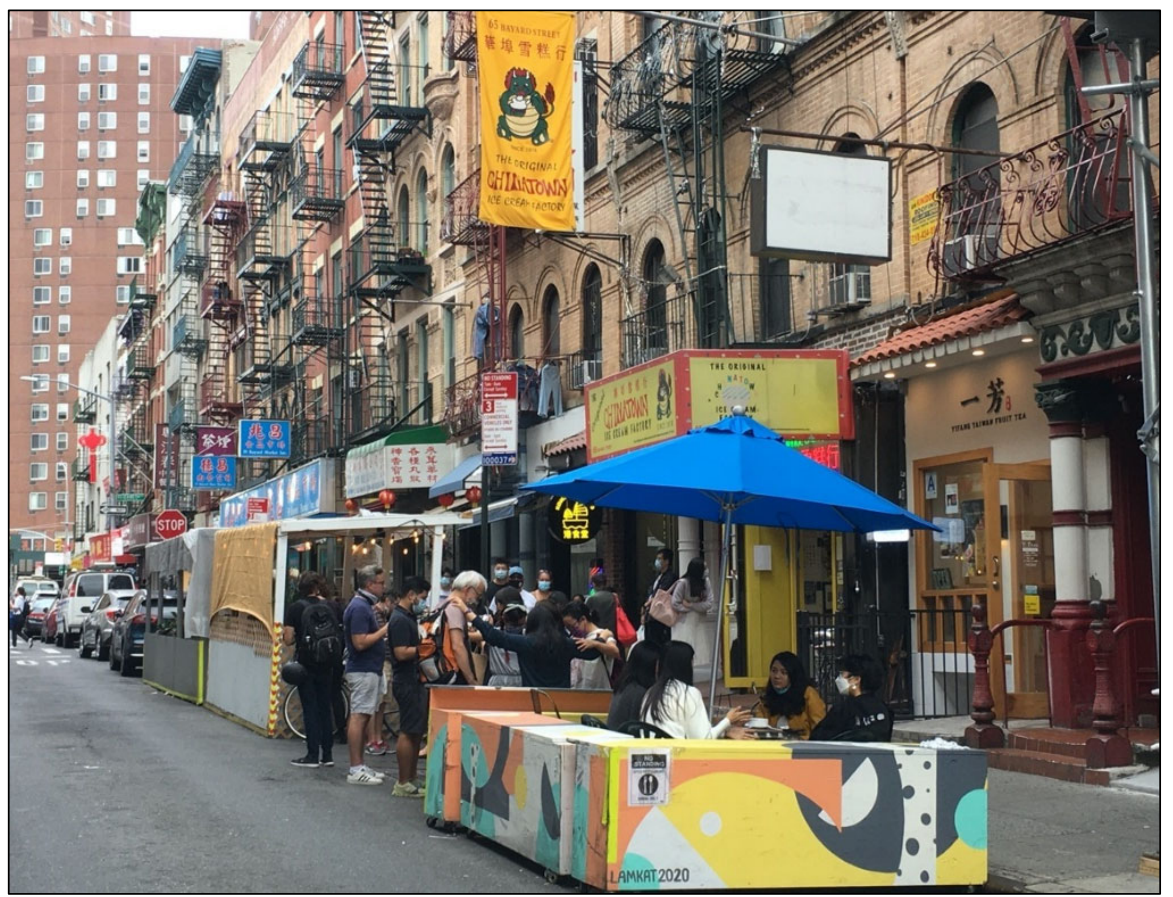

Figure 2. People enjoy outdoor dining on a warm Saturday in late September 2020 thanks to Assembly for Chinatown. Photo by author. multi-ethnics, curious to eat the food of others, taking pleasure in new culinary experiences and mixing culinary traditions and flavors in single dishes to make something new, but also easily revert to fear when threatened (Gabaccia, 1998). The irony of Chinatown is that its food system arose from the codified discrimination of the early 1900s. Now that it is no longer solely an immigrant ghetto, competition for the right to its urban space and pressures on the farmland that supplies it has started to disrupt its structure. If we do not recognize the multiple cultures and peoples that our ethnic, immigrant neighborhoods support, service, and appeal to, and the structures and processes that make them successful, we lose the chance to grow food equity in our cities.

\section{References}

Barron, J. (2020, February 4). Coronavirus in N.Y.: Without Chinese tourists, business sags. The New York Times. Retrieved from https://www.nytimes.com/2020/02/04/nyregion/coronavirus-nyc.html

City as Living Laboratory [CALL]. (2020). Mapping Chinatown's food system. Retrieved from https://www.cityaslivinglab.org/chinatown/map

Campbell, C. G., \& McAvoy, G. (2020). Florida fruit and vegetable growers' adaptation and response to Covid-19. Journal of Agriculture, Food Systems, and Community Development, 9(4), 1-5. https://doi.org/10.5304/jafscd.2020.094.032

Johnson, C. (2019). Growing food equity in New York. City: A city council agenda. Retrieved from https://council.nyc.gov/data/food-equity/

Gabaccia, D. R. (1998). We are what we eat: Ethnic food and the making of Americans. Cambridge, MA: Harvard University Press.

Garcia, M. E., DuPuis, M., Mitchell, D. (Eds.). (2017). Food across borders. Newark, NJ: Rutgers University Press. https://doi.org/10.36019/9780813592008

Ginanneschi, M. (2020). The future of food after Covid-19 through the lens of anthropology. Journal of Agriculture, Food Systems, and Community Development, 9(4), 1-3. https://doi.org/10.5304/jafscd.2020.094.027 
Hum, T. (2014). Making a global immigrant neighborhood: Brooklyn's Sunset Park. Philadelphia, PA: Temple University Press. https://doi.org/10.2307/i.ctvrdf40j

Imbruce, V. (2016). From farm to Canal Street: Chinatown's alternative food network in the global marketplace. Ithaca, NY: Cornell University Press. https://doi.org/10.7591/9781501701238

King, M., Fu, W. J-C., Brown, M., \& Santacaterina, D. (2020, May). Rumor, Chinese diets, and Covid-19. Virtual Panel Presentation conducted by Carolina Asia Center: University of North Carolina, Chapel Hill, NC. Retrieved from https://www.facebook.com/CarolinaAsiaCenter/videos/819370115255947/

Ku, R. J-S., Manalansan IV, M. F., \& Mannur, A. (2013). Eating Asian America: A food studies reader. New York, NY: New York University Press.

Li, B. Y. (2011). Chinatown then and now. Retrieved from Asian American Legal Defense Fund website:

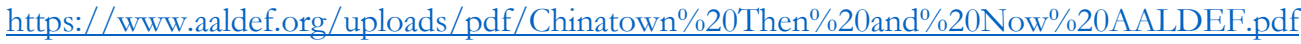

Mintz, S. W. (1996). Tasting food, tasting freedom: Excursions into eating, culture, and the past. Boston, MA: Beacon Press.

Ray, K. (2016). The ethnic restauranteur. London: Bloomsbury Academic. https://doi.org/10.5040/9781474269414

Sietsema, R. (2020, April 9). A tour of a transformed Chinatown, where vital restaurants and grocery stores soldier on. Eater NY. Retrieved from https://ny.eater.com/2020/4/9/21214894/chinatown-nyc-coronavirus-restaurants-grocery-store-open

Yi, S., Ali S., Russo, R., Foster, V., Radee, A., Chong, S., Tsui, F., Kranick, J., Lee, D., Imbruce, V., \& Mezzacca, T. A. (2020). Changes to the food retail environment due to Covid-19: A snapshot of the New York City experience May to July 2020. Manuscript submitted for publication.

Young, G. (2020). Coronavirus: Chinatown stories. Poster House. Retrieved from https://posterhouse.org/special-project/corona-virus-chinatown-stories/

Zukin, S. (2010). Naked city: The death and life of authentic urban places. New York, NY: Oxford University Press. https://doi.org/10.1093/oso/9780195382853.001.0001 